\title{
10. Participation and participation rights in EU law and governance
}

\section{Joana Mendes*}

\section{INTRODUCTION}

Participation is ubiquitous in EU law and governance. Participatory phases are found in decisional procedures defined in many regulations and directives, be these an obligation impinging upon Member States, be they a procedural duty of EU administrative bodies, either determined by the EU legislator or self-imposed. Participation can, therefore, be seen as a dominant feature of the governance arrangements which have developed over the last decades. ${ }^{1}$

However, since participation has manifold meanings, the extent of this pervasion may be deceptive. This is the case if one intends participation as the procedural intervention of natural and legal persons whose substantive rights and interests are potentially affected by a Community regulatory measure, with a view both to ensuring the procedural protection of those rights and interests and to attaining an accurate representation of the factual situation based on an exact representation and consideration of the interests involved on the part of the deciding body.

This chapter argues that there is a mismatch between, on the one hand, the powers exerted by the European administration, particularly taking into account the effects which they may have in the legal sphere of persons concerned, and, on the other, the procedural guarantees which are afforded to them under the right to be heard as this has been developed by the Community Courts. Considered the core of the rights of the defence, the right to be heard, as it has been shaped by the Courts is a tributary of an adversarial, bilateral conception of the procedure, and is thus primarily recognised to addressees of unfavourable administrative decisions, and,

* This chapter is based on the doctoral research I am developing at the European University Institute, under the supervision of Professor Jacques Ziller.

1 Joanne Scott and David Trubek, 'Mind the Gap: Law and New Approaches to Governance in the European Union', [2002] European Law Journal 1, at 5. 
more broadly, to those directly and individually concerned by them. As such, the procedural protection of persons affected by European administrative action is also limited to procedures leading to the adoption of individual decisions. It will be shown that the subjective and objective limits thus placed on participation rights are not only unsuited to the procedural protection of holders of legitimate interests affected by European administrative action, but are also unjustifiable in the light of the rationales of participation defended by the European Courts (ECJ and CFI).

The argument will be developed as follows. In the first section, the various usages of the concept in different contexts of EU law and governance will be illustrated, on the basis of a brief account of the meanings of participation. This will illustrate that a 'thicker' meaning of participation, capable of grounding procedural guarantees to persons affected in their legal spheres by European regulatory measures, is virtually absent from the EU governing and administrative structures, as shaped by the Commission's governance initiatives. At the same time, the narrower legal approach to participation, which can be seen in the Court's jurisprudence, is excessively restrictive for this purpose, for the reasons briefly presented above. These reasons will be developed in the second part of the chapter, where the limits to the Court's approach to participation rights will be highlighted. Finally, the third section will examine the criteria that, drawing on the concept of participation propounded above, may guide the recognition of participation rights in a way that is more consonant with the breadth of EU regulatory powers and with the complexity of the administrative relationships that emerge thereupon.

\section{THE PLURAL FACETS OF PARTICIPATION}

Participation, in its simplest and most general form, can be described as the opportunity to take part in decision-making processes. ${ }^{2}$ In this broad sense, it comprises both the participation of public entities in decisionmaking processes which are attributed to the competence of a different entity or administration, on the one hand, and the involvement of the public or of interest holders in the exercise of public functions, on the other. The former phenomenon is particularly frequent in complex, multilayered administrative systems and stems from the need to ensure administrative collaboration among different services and different levels of

2 This first approach is often present in writings on participation. Among others, Mario Chiti, Partecipazione popolare e pubblica amministrazione, Pacini Editore (Pisa, 1977), pp. 34-35. 
administration, or, more strictly, to respect the allocation of competences among them when they are implicated in a given decision. The latter is the subject of this chapter. ${ }^{3}$ In this latter sense, it is possible analytically to distinguish multiple meanings of participation, according to the rationales underlying the intervention of private parties. In reality, these are often intertwined and it is not always easy to isolate one from the other.

Firstly, participation may be grounded on the need to gather information on the factual situation which will be decided upon. Administrations have limited resources, at least in the face of the technical complexity implied in regulatory options. Regulatees are often better placed to provide the information needed for decision-making, without prejudice to other sources which the decisional body may resort to. Secondly, participation may be a means of ensuring the responsiveness of regulatory decisions. Calling interested parties to intervene in decisional procedures and, eventually, to influence regulatory outcomes arguably allows enacted rules to be more in tune with to the social and economic needs of the regulated sector. Thirdly, the intervention of interested parties prior to the adoption of the final decision arguably favours compliance and facilitates implementation. Having been able to take part in the decisional process and, possibly, to have their views reflected or attended to in the final act or to understand the reasons why this was not the case enhances adherence to the regulatory option of the decisional body and, thus, abidance. In these three senses, participation is instrumental to the effectiveness of decision-making. In so far as the intervention in the procedure of parties external to the institutionalised decisional structure is directed at facilitating the fulfilment of the decisional function, participation assumes in these three cases a function of collaboration with the decision maker. Ultimately, it may be superseded by other regulatory techniques which ensure the same goals. ${ }^{4}$

A fourth, stronger, meaning of participation is grounded on ensuring respect for the dignity of the persons affected by regulatory decisions. Participation, in this sense, is grounded on the 'moral imperative' of allowing the persons concerned to defend their subjective rights and

\footnotetext{
3 Although the participation of public entities in decisional procedures has, in general, different rationales from the participation of private persons, these two phenomena can be equated in certain cases. For example, the procedural intervention of a public entity in order to respect its attributed competences is, in a way, similar to the participation of private persons ensured to respect the public interference in their legal spheres.

4 Joined cases T-371/94 and T-394/94, British Airways and Others v. Commission [1998] ECR II-2405, paras. 60 and 64.
} 
interests before the adoption of a decision which may negatively impact on their legal sphere (audi alteram partem). Finally, participation can be understood as a tool for 'public-making', ${ }^{5}$ enhancing democracy by promoting 'active citizenship' through complementary means to those typical of democratic representation. The 'public', 'the civil society' or 'the citizens' (without any further qualification which restricts access to the procedure) are called upon to intervene in regulatory processes, and this is perceived as a means of creating an active public, or, at least, of avoiding public disaffection with political institutions. A weaker manifestation of this meaning may be identified in participatory mechanisms primarily directed at ensuring the transparency of decisional processes.

\subsection{Participation in EU Governing and Administrative Structures}

These different meanings permeate the EU governing and administrative structures. The consultative committees defined in the Treaty reveal the concern to involve interested parties in the Community rulemaking activity, arguably due to the instrumental reasons of responsiveness and compliance. Beyond the activity of these committees, the collaboration of persons concerned by Community regulatory activity in the form of their procedural intervention in decisional processes is a longstanding and entrenched feature of Community decisional structures. This is due not only to a fairly reduced administrative apparatus when compared to the tasks that the Community performs, ${ }^{6}$ but also to the need, felt in particular by the Commission, to create a proper constituency, in the line of the neo-functionalist trend dominant during the first period of integration. $^{7}$

The practice by the Commission of consulting national administrations, private experts and interest groups, both when defining the contours of Community policies and when delineating the practical conditions of

5 This expression was suggested by Professor Neil Walker (recognising the lack of a more adequate term) in a discussion I had with him on participation. I thank him for clarifications on the systematisation I present in this section.

6 The relationship between a reduced administrative apparatus and resort to collaboration of concerned parties is explicit in the Treaty which established the European Coal and Steel Community. Indeed, Article 5, while defining in broad terms the competences of the Community, determined that these were to be carried out by the institutions 'with a minimum of administrative machinery and in close co-operation with the parties concerned' (emphasis added).

7 Justin Greenwood, Interest Representation in the European Union, Palgrave Macmillan (Basingstoke, 2003), p. 4. 
application for those policies, is well-known. ${ }^{8}$ This practice has given rise to the creation of diverse committees, among which interest committees composed of representatives from the social and economic sectors concerned set up to ensure their input in decision-making (for example, the advisory groups dealing with matters covered by the common agricultural policy). ${ }^{9}$ In some cases, representatives from interest groups take part in comitology committees' discussions and negotiations, contrary to what is statutorily defined..$^{10}$ More broadly, the Commission often resorts to various forms of consultation in order to gather technical information and to ensure the responsiveness of its regulatory policies (for example publication of consultative documents, such as green and white papers, internet consultations and hearings of specific groups through workshops, conferences or seminars). Often, the legislator defines the consultation duties impinging directly on Community administrative bodies.

The intent to seek the collaboration of interested parties and the one to open up decisional procedures in order to ensure transparency and the adherence of specific publics often converge in these consultation mechanisms and duties. In some cases, however, it is possible to isolate one of the two meanings as the prevailing rationale for participation. So, for example, the public inquiry period regarding the scientific opinion of the European Food and Safety Authority envisaged for the authorisation, modification, suspension and revocation of the marketing authorisations of genetically modified food and feed (in line with the principles defined in the general food safety regulation) is destined to ensure the transparency of these procedures and thereby to tackle the risk of public mistrust regarding Community decisions. Two arguments support this

8 For an early account, Emil Noël, 'Comment fonctionnent les institutions de la Communauté Économique Européenne’ [1963] Revue du Marché Commun 14, at p. 20.

9 Dating back to the 1960's, they are now regulated by Decision 2004/391/EC of 23 April 2004, OJ (2004) L 120/50.

10 Peter van der Knaap, 'Government by Committee: Legal Typology, Quantitative Assessment and Institutional Repercussions of Committees in the European Union', in Robin H. Pedler and Günther F. Schaefer, Shaping European Law and Policy. The Role of Committees and Comitology in the Political Process, European Institute of Public Administration (Maastricht, 1996) pp. 83, at p. 101. Annette Töller, 'The "Article 19 Committee": the Regulation of the Environmental Management and Audit Scheme', in M.P.C.M van Schendelen (ed.), EU Committees as Influential Policymakers Ashgate (Aldershot, 1998) pp. 179, at p. 181-182. No mention of this practice is found in the Report from the Commission on the working of committees during 2005 (COM(2006)446 final, Brussels, 9 August 2006), which unsurprisingly is confined to the formal functioning of the comitology committees. 
interpretation: first, the fact that no particular connection to the subject matter is required to access the procedure - comments are received from 'the public' in general - and, secondly, the fact one of the regulatory concerns in this sector is to ensure consumer confidence in the decisionmaking processes underpinning food law. ${ }^{11} \mathrm{~A}$ different rationale grounds the consultation of interested parties 'regarding the form in which applications for authorisation [of medicinal products] are to be presented' as well as the drafting of the structure and level of fees paid by undertakings to obtain and maintain Community marketing authorisations, envisaged in the legal regime for the authorisation and supervision of medicinal products. This consultation is arguably grounded on the need to secure the collaboration of persons concerned in the definition and implementation of these rules. ${ }^{12}$

In a different way, giving rise to distinct types of decision-making, some participation practices have mutated into forms of involvement of private persons in decisional processes where they acquire formal decisional powers - the 1985 'new approach to harmonisation' is but one example or negotiating powers - a different technique of involvement of concerned parties which can be exemplified by the partnership principle in the management of structural funds. ${ }^{13}$

Taking into account its pervasiveness across policy sectors, one may claim that participation is an inbuilt and reflexive feature of the European polity. Participation in this context is essentially intended as a means of enhancing the decisional function and its regulatory effects (in the triple

11 Articles 9 (7), 10 (1), 18 (7) and 22 (1) of Regulation 1829/2003, of the European Parliament and of the Council, of 22 September 2003, on genetically modified food and feed OJ (2003) L 268/1. Also Article 9 of recital 5 and 9 and 22 of the preamble to Regulation 178/2002, of the European Parliament and of the Council, of 28 January 2002, laying down the general principles and requirements of food law, establishing the European Food Safety Authority and laying down procedures in matters of food safety OJ (2002) L 31/1.

12 Articles 6(4) and 70(1) of Regulation 726/2004, of the European Parliament and of the Council, of 31 March 2004, laying down Community procedures for the authorisation and supervision of medicinal products for human and veterinary use and establishing a European Medicines Agency OJ (2004) L 136/1.

13 Now enshrined in Article 11 of Council Regulation 1083/2006, of 11 July 2006, laying down general provisions on the European Regional Development Fund, the European Social Fund and the Cohesion Fund and repealing Regulation (EC) No 1260/1999, OJ (2006) L 210/25. On the distinction between non-decisional participation and these various forms of public-private regulation, see Fabrizio Cafaggi, 'Rethinking Private Regulation in the European regulatory space', in Fabrizio Cafaggi (ed.), Reframing Self-regulation in European Private Law, Alphen aan den Rijn: Kluwer Law International, (2006) p. 3, at pp. 22-35. 
meaning mentioned above) but it is also pervaded by a sense of reaching out to specific publics. Recent normative developments have furthered its instrumental use and, at least in appearance and in certain contexts, have imbued participation with a fully-fledged connotation of 'public-making'. The 2001 White Paper on Governance is a conspicuous example of this blend of meanings of participation. There, most notably, participation is dressed up by the rhetoric of '[connecting] Europe closer to its citizens'. ${ }^{14}$ Nevertheless, the 'principle of participation' as adopted in the White Paper essentially perpetuated former practices of consultation and interest representation which were eventually retouched and better structured due to the Commission's search for social legitimacy. ${ }^{15}$ At the same time, the wording of the principle of participatory democracy, first enshrined in the Constitutional Treaty and now in the Lisbon Treaty, represents little more than a crystallisation of the abovementioned practices. ${ }^{16}$ Concretely, among other developments, consultation became one of the pillars of the Commission's strategy of better law-making, inserted into procedures of impact assessment. ${ }^{17}$ Moreover, specific regulatory approaches have been developed where the involvement of concerned parties is of central relevance (for example, the Lamfalussy regulatory approach in the field of financial services, where involvement of market practitioners is destined

14 Commission of the European Communities, 'European Governance. A White Paper', COM(2001)428 final, Brussels, 25 July 2001, p. 8.

15 The claimed principle of participation is formulated thus: ' $[\mathrm{t}] \mathrm{he}$ quality, relevance and effectiveness of EU policies depend on ensuring wide participation throughout the policy chain - from conception to implementation. Improved participation is likely create more confidence in the end result and in the (i) nstitutions which deliver policies. Participation crucially depends on central governments following an inclusive approach when developing and implementing EU policies': White Paper, cit. (n.14), p. 10.) On this, Kenneth A. Armstrong, 'Rediscovering Civil Society: the European Union and the White Paper on Governance' (2002) 8 European Law Journal 102; Paul Magnette, 'European Governance and Civic Participation: Beyond Elitist Citizenship?' (2003) 51 Political Studies 144.

16 Future Article $8 \mathrm{~B}(1)$ to (3) of the EU Treaty, following amendment by Treaty of Lisbon, OJ (2007) C 306/1. Article I-47(1) to (3) of the Treaty establishing a Constitution for Europe, OJ (2004) C 310/1.

17 Communication from the Commission, 'European Governance: Better Lawmaking', COM(2002)275 final, Brussels, 5 June 2002, p. 3; Communication from the Commission, 'Towards a reinforced culture of consultation and dialogue - General principles and minimum standards for consultation of interested parties by the Commission', COM(2002) 704 final, Brussels, 11 December 2002, p. 15. Highlighting the limited scope of application of these principles and standards, Paul Craig, EU Administrative Law, Oxford University Press (Oxford, 2006) p. 135. 
to ensure inclusiveness and acceptance, as well as better rulemaking ${ }^{18}$ ). However, the thicker meaning of participation, underpinned in respect for the dignity of the person, capable of ensuring procedural protection to persons affected by regulatory measures, is virtually absent from these developments.

\subsection{Participation in the Case Law of the EU Courts}

The stricter legal approach to participation contained in the case law of the EU Courts reveals a narrower picture than the one depicted above. Participation assumed in this context the form of a right to be heard, recognised 'in all proceedings initiated against a person which are liable to culminate in a measure adversely affecting that person' and considered 'a fundamental principle of Community law which must be guaranteed even in the absence of any rules governing the procedure in question'. ${ }^{19}$ Arguably, the core justifying criterion for applying the audi alteram partem principle lies in the adverse effect that an administrative decision may have vis-à-vis individual parties, ${ }^{20}$ which corresponds to the fourth meaning of participation outlined above. Participation has the function of defence, affording anticipated procedural protection to affected interests, and it is thus seen as a complement to judicial review, as the participant is able to contradict the possible future decision, invoking errors, flaws or mistakes which might lead to the illegality of the final act. ${ }^{21}$ The intervention of the person targeted by the administrative procedure is grounded on a principle of justice. It is a formality required by the rule of law, being typical of individual procedures from which sanctions or

18 'Final Report of the Committee of Wise Men on the Regulation of European Securities Market', Brussels, 15 February 2001, pp. 32-33 (available at http://ec.europa.eu/internal_market/securities/docs/lamfalussy/wisemen/finalreport-wise-men_en.pdf). See also Article 5 of Commission Decision 2001/527/EC, of 6 June 2001, establishing the Committee of European Securities Regulators, OJ (2001) L 191/43, amended by Commission Decision 2004/7/EC of 5 November 2003, OJ (2001) L 3/32.

19 For example, Case 234/84, Belgium v. Commission [1986] ECR 2263, para. 27; Case C-135/92, Fiskano v. Commission [1994] ECR I-2885, para. 39; Case T-260/94, Air Inter v. Commission [1997] ECR II-997, para. 59.

20 Hanns Peter Nehl, Principles of Administrative Procedure in EC Law, Hart Publishing (Oxford, 1999), pp. 71 and 84.

21 Referring to Italian administrative law, but of general relevance, Massimo Occhiena, 'Partecipazione al procedimento amministrativo', in Sabino Cassese (ed.), Dizionario di Diritto Pubblico, Giuffrè (Milan, 2006), vol. V, p. 4128, at p. 4134 . 
penalties may emerge or in which a potential advantageous position is denied to an applicant. ${ }^{22}$

However, the right to be heard also emerges in the Courts' jurisprudence as an objective procedural standard which structures the exercise of administrative powers, be it because it ensures the position of affected private parties, be it because it enables the administrative authority to correctly assess the factual situation which it is called upon to appreciate. In this sense, the rationale of the right to be heard lies in a principle of care, according to which the administrative authorities should carry out a scrupulous examination of the facts and take into account all their possible facets, parallel to the second meaning of participation indicated above. ${ }^{23}$ The stance according to which an infringement of the right to be heard can only lead to the annulment of the decision on procedural grounds if the applicant challenging the validity of the 'irregular' decision can prove that this would have been different otherwise converges with this interpretation, as it enhances the objective side of the right to be heard. ${ }^{24}$ This dualism participation grounded on the dignity of the person and participation as a factor which contributes to the correct exercise of the administrative

22 This stance underlined judgments such as the ones issued in Case 17/74, Transocean Marine Paint Association v. Commission [1974] ECR, 1063, at paras 15 and 16; in Case 85/76, Hoffmann-La Roche \& Co. AG v. Commission [1979] ECR 461, at paras 9 and 15; in Joined cases 46/87 and 227/88, Hoechst $A G v$. Commission [1989] ECR 2859; at paras 13 to 15 and 52; Case C-49/88, Al-Jubail Fertilizer Company (Samad) and Saudi Arabian Fertilizer Company (Safco) v. Council [1991] ECR I-3187, at paras 15 to 18; as well as in Case T-450/93, Lisrestal - Organização Gestão de Restaurantes Colectivos Ld $d^{a}$ and others v. Commission [1994] ECR II-1177, at paras 42, 45, 47 and 48 and in Case C-32/95 P, Commission v. Lisrestal - Organização Gestão de Restaurantes Colectivos Ld $d^{a}$ and others [1996] ECR I-5373, at paras 24, 26 to 30 and 33.

23 Cf., for example, Case 34/77, Jozef Oslizlok v. Commission [1978] ECR 1099, at para. 18, or, more noticeably, Case C-269/90, Technische Universität München v. Hauptzollamt München-Mitte [1991] ECR I-5469, at paras 13, 14 and, especially, 24. The Court has extended procedural protection of concerned parties on the basis of the principle of care, which it clearly separates from the right to be heard (in Case T-167/94, Detlef Nölle v. Council and Commission [1995] ECR II-2589, paras 63 and 78; see next section, below). On this, Nehl, cit. (n.20), Chapter 9.

${ }_{24}$ The Court has not been consistent in this point. Tridimas considers that the stance referred to in the text is the dominant one (Takis Tridimas, The General Principles of EU Law, 2nd edition, Oxford University Press (Oxford, 2006), pp. 391 and 392. Nehl points out cases where the Court adopted a different stance, but underlines the limitations of withdrawing consequences from this development: cit. (n.20), pp. 97-98. For an intermediate stance, closer to the latter, see Case T-147/97, Champion Stationery Mfg Co. Ltd and others v. Council [1998] ECR II-4137, para. 79 and Case C-194/99, Thyssen Stahl v. Commission [2003] ECR I-10821, para. 31 . 
function - has accompanied the jurisprudential developments in this matter. ${ }^{25}$

\section{LIMITS TO PARTICIPATION RIGHTS IN EU LAW}

The Courts have maintained a pragmatic approach to participation, refraining from constructing a consistent doctrinal basis for the right to be heard. Although it is possible to identify situations where the right will be granted more likely than not, ${ }^{26}$ outside its core purview (adjudicatory, trial-type administrative procedures which may produce adverse effects in the legal sphere of the addressees of individual decisions) and the fields of law where it has been recognised, the final conclusion remains dependent on the judicial appreciation of each case. In the end, the Courts' possibly purposeful pragmatism leaves room to accommodate different solutions. ${ }^{27}$ This relative character of the right to be heard has been highlighted in Yusuf and Kadi, where the fundamental rights and the type of restriction at issue implied the need to comply with the rights of the defence of the individuals concerned, even if at only a subsequent phase of the procedure. ${ }^{28}$

Furthermore, two boundaries limit the permissible scope of rights of participation. First, the right to be heard has been chiefly recognised to legal or natural persons or public bodies targeted by administrative decisions, or to persons who are adversely affected by those decisions in a similar manner. The Courts' jurisprudence has been

${ }_{25}$ Eric Barbier de La Serre, 'Procedural Justice in the European Community Case-law Concerning the Rights of the Defence: Essentialist and Instrumentalist Trends' (2006) 12 European Public Law 225, in particular pp. 228-229.

26 On this see ibid., p. 248.

27 See Nehl, cit., pp. 95 and 98, who is critical, and Barbier de La Serre, cit., pp. 248-250, upholding this pragmatism with some reservations.

28 Case T-306/01, Ahmed Ali Yusuf and Al Barakaat International Foundation v. Council and Commission [2005] ECR II-3533, at paras 326 and 327; Case T-315/01, Yassin Abdullah Kadi v. Council and Commission [2005] ECR II-3649, at paras 256 and 257. Beyond the respect of the rights of the defence, these cases raise important questions pertaining, in particular, to the relations between Community and international law and the jurisdiction of Community Courts to review Community acts which implement resolutions adopted by the United Nations Security Council. The judgments were controversial and these issues have been widely debated in the literature. Specifically on the right to be heard, see joined Cases C-402/05 P and C-415/05 P, Yassin Abdullah Kadi and Al Barakaat International Foundation v. Council and Commission [2008] nyr., para. 333 to 348, as well as Opinion of Advocate General Maduro, delivered on 16 January 2008 in Case C-402/05 P, Yassin Abdullah v. Council and Commission nyr., para 47 and 51 to 53. 
predominantly underpinned in an adversarial-adjudicative conception of process rights, ${ }^{29}$ and this has arguably limited the expansion of participation rights to the intervention of other interested parties. ${ }^{30}$ Apart from the specific procedures where intervention of interested parties is expressly envisaged (for example, competition, anti-dumping, Community trademark), ${ }^{31}$ holders of legitimate interests and of general interests the closeness of which to the material relationship at issue could justify extended legal protection or the input of which could contribute to a sound decision may be denied legally protected and judicially enforceable participation rights.

There are, however, in the Court's case law, indications which allow us to overcome this limitation. In some judgments, the Courts went beyond the strict formality of procedures, in particular the bilateral scheme of the relationship established between the deciding body and the person targeted by an administrative measure, and took into account the position which other private parties have in relation to the administrative decision. In Lisrestal, the Court recognised the right to be heard of the beneficiary of the European Social Fund, even though the beneficiary was not the interlocutor of the Commission, on the grounds that he was directly concerned and adversely affected by a decision reducing the amount of the aid granted. The most significant statement in this judgment is that the applicable regulation, determining the competence of the Commission to suspend, reduce or withdraw aid and to order the refund of paid amounts for which beneficiaries have primary liability establishes a direct link

29 The 'trial-type-of-process' origin of the right to be heard is well expressed by the use of the term 'droits de la défense' or 'rights of the defence', often used in the Courts' jurisprudence. The influence of this judicial conception is equally shown in the reasoning of some judgments and in the reference to the need to ensure the right to be heard 'in all procedures, even of administrative nature' (Case 85/76, Hoffmann-La Roche v. Commission [1979] ECR 461, at para. 9; Joined cases 100 to 103/80, SA Musique Diffusion française and others v. Commission [1983] ECR 1825, at para. 10; Case T-11/89, Shell International Chemical Company Ltd v. Commission [1992] ECR II-757, at para. 39; Thyssen Stahl, cit. (n. 24), at para. 30). It is, moreover, confirmed by the wording frequently reiterated by the Courts: 'respect for the rights of the defence is, in all proceedings initiated against a person which are liable to culminate in a measure adversely affecting that person, a fundamental principle of Community law which must be guaranteed even in the absence of any rules governing the proceedings in question' (e.g. Belgium v. Commission, cit. (n. 19), at para. 27; Fiskano, cit. (n. 19), at para. 39; Air Inter, cit. (n. 19), at para. 59; Yusuf, cit. (n. 28), at para. 325; Kadi, cit. (n. 28), 255).

30 Similarly to what may occur at national level. For the English case, Paul Craig, Administrative Law, 5th edition, Sweet and Maxwell (London 2003), p. 409.

31 See, below, section 4.2. 
between these and the Commission. ${ }^{32}$ In Nölle, the Court, faithful to a bilateral view of the administrative relationship, considered that no right to be heard could be recognised accorded to an independent importer in the realm of an anti-dumping procedure on the ground that this 'was not against the applicant and could not for that reason result in a measure adversely affecting it'. However, the independent importer could access the procedure, on the grounds that it had demonstrated a 'sufficient interest as an "interested party" for the purpose of taking part in the anti-dumping procedure. It follows that the Commission, in accordance with the principle of care, must 'consider seriously and in detail whether [the] arguments or proposals [invoked by the interested party] are well founded'. The principle of care is thus intended as 'a rule protecting individuals'. ${ }^{33}$

A second limitation to participation rights pertains to the realm of acts to which the right to be heard is applicable. The Court has sustained that this right, intended as a general principle of law when exercised in individualised administrative procedures, cannot be transposed to the realm of general acts involving a choice of economic policy. The Court first grounded this stance on the need to respect the Treaty determinations in relation to consultation as well as the democratic principles stemming from the Treaty (Atlanta). In subsequent judgments, however, this reasoning was extended to general acts adopted on the basis of a regulation or directive (for example, Bergaderm).$^{34}$ Any possibility of legally enforced participation (and, hence, anticipated legal protection) in relation to a wide range of administrative regulatory acts is thus excluded, whenever rights of participation have not been expressly enshrined in a Treaty Article or in Community legislation, even when substantive rights and interests are effectively affected by general rules. The cases in which the Court has recognised the right to be heard in procedures leading to the adoption of general acts are clearly circumscribed - investigative proceedings prior to the adoption of anti-dumping regulations, given the partially individualised nature of the latter (they are applicable to specific imported

32 Lisrestal v. Commission, cit. (n. 22), paras 47 and 48 (see also paras 43 to 45), and Commission v. Lisrestal, cit. (n. 22), paras 28 and 29.

33 Nölle, cit. (n. 23), paras 63 and 78. For a sharp criticism of this judgment, Nehl, cit. (n. 20), pp. 76-7. Nehl notes that the scope of the principle of care in not clear, in particular it is not always easy to delimit it from the scope of the rights to be heard (cit., pp. 110-111, 131-132, 162-163).

34 Case T-521/93, Atlanta AG and others v. Council and Commission [1996] ECR II-1707, at paras 70-72; Case C-104/97 P, Atlanta $A G$ and others v. Commission and Council [1999] ECR I-6983, at paras 37 and 38 (and, before, in Case T-199/96, Laboratoires pharmaceutiques Bergaderm SA and Jean-Jacques Goupil v. Commission [1998] ECR II-2805, at paras, 50, 58 and 59.) 
products and are thus susceptible to producing adverse consequences and affecting 'directly and individually' the undertakings concerned). ${ }^{35}$ In addition, the requirement of 'direct and individual concern', the condition for access to justice under Article 230 (4) EC, has been considered irrelevant for the purposes of access to rulemaking procedures. ${ }^{36}$ This stance may void the procedural protection of individuals in European law in cases where general rules tend to replace individual decisions as a form of regulation, but where the rules adopted may be sufficiently detailed to impact on individuals' legitimate interests. ${ }^{37}$

Arguably, the connections between access to administrative procedures and access to justice have been a fundamental barrier to further jurisprudential developments in this matter, ${ }^{38}$ especially as far as extending the procedural protection afforded by rights of participation to persons other than those individually and directly concerned by a given act, and, thereby, to general and abstract acts (with the mentioned exception of anti-dumping regulations is concerned). Underlying the Courts' stance is the assumption that sustaining participation in rulemaking procedures or expanding procedural rights beyond what is determined in the Treaty or in secondary legislation goes against the Courts' powers under the Treaty. ${ }^{39}$

35 Case C-49/88, Al-Jubail Fertilizer Company (Samad) and Saudi Arabian Fertilizer Company (Safco) v. Council of the European Communities [1991] ECR I-3187, para. 15. Opinion of AG Darmon delivered on 7 February 1991 in Al-Jubail [1991] ECR I-3205, at paras 72 to 75), drawing on the Opinion of AG Warner delivered on 14 February 1979 in Case 113/77, NTN Toyo Bearing Company and others v. Council [1979] ECR 1212, p. 1262.

36 Case T-13/99, Pfizer Animal Health SA v. Council [2002] ECR II-3305, at paras 88-105 and 487, and Case T-70/99, Alpharma Inc. v. Council [2002] ECR II-3495, at paras 80-97 and 388 .

37 On this, Craig, EU Administrative Law, cit. (n. 17), pp. 318-322.

38 These have been underlined by the Courts, for example, in Case C-198/91, William Cook plc v. Commission [1993] ECR I-2487, at para. 23; Case C-225/91, Matra v. Commission [1993] ECR I-3203, at para. 17). In Pfizer and Alpharma, the reverse situation occurred: direct and individual concern was recognised to access judicial review, but considered unsuited to ground a right to be heard (see footnote 37). The result is, however, the same: recognising a right to be heard in Pfizer and Alpharma, when at stake was a procedure leading to the adoption of a regulation, would open Pandora's box.

39 Atlanta (CFI judgment), at para. 71 and Atlanta (ECJ judgment), at para. 38 ('In the context of a procedure for the adoption of a Community act based on an article of the Treaty, the only obligations of consultation incumbent on the Community legislature are those laid down in the article in question') and Case T-198/01, Technische Glaswerke Ilmenau GmbH v. Commission [2004] ECR II-2717, at para. 194 ('the Community Court cannot, on the basis of the general legal principles relied on by the applicant, such as those of the right to due process, 
In addition, the political implications of an expansion of participation, often emphasised by the Commission in its initiatives to 'bring the citizens closer to the European institutions', have possibly prevented a more favourable jurisprudential stance in relation to participation rights.

However, this leads to a mismatch between the powers exercised by Community administrative bodies and the procedural protection of the persons concerned: the scope of procedural protection afforded by Community rules and principles does not accompany the power to interfere in the person's legal sphere. A food business operator may have charges and duties imposed on him without having had the opportunity to express his views in the corresponding procedure (the procedure that led to the decision imposing charges and duties), where the conditions for the use of the products he deals with are determined market by a regulation following a procedure initiated by another person. ${ }^{40} \mathrm{~A}$ consumer organisation the input of which into decisional procedures is in principle looked upon favourably cannot claim a participation right on which to ground its procedural intervention and related claims. ${ }^{41}$ Further, in most cases where the Courts have extended participation or some of the related procedural guarantees to interested parties other than the person on whose sphere the administrative act directly impinges, they remain faithful to an adversarial conception of the administrative procedure which involves the administration and the person targeted by the administrative decision in a bilateral relationship, other persons being considered third parties to the proceedings. ${ }^{42}$ While this may be accurate in some situations, in others it

the right to be heard, sound administration or equal treatment, extend the procedural rights which the Treaty and secondary legislation confer on interested parties in procedures for reviewing State aid').

${ }_{40}$ Cf. procedure for the approval of smoke flavourings used or intended for use in or on foods, ruled by Regulation 2065/2003, of the European Parliament and of the Council, of 10 November 2003, OJ (2003) L 309/1, in particular Article 9 (4).

41 Case C-170/89, Bureau Européen des Unions de Consommateurs v. Commission [1991] ECR I-5709, at paras 19-21.

42 Nölle, cit. (n. 20), at paras 63 and 76. Technische Glaswerke, cit. (n. 39), at paras 60 and 61. Even Lisrestal, despite the breakthrough, is still indebted to this conception (Lisrestal, cit. (n. 22), paras 43 and 45). Arguably, in Al-Jubail this conception is not so markedly dominant (given the hybrid nature of anti-dumping regulations). Yet, it is present in the formulation of the right to be heard: '[requirements stemming from the right to a fair hearing] must be observed not only in the course of proceedings which may result in the imposition of penalties, but also in investigative proceedings prior to the adoption of anti-dumping regulations which, despite their general scope, may directly and individually affect the undertakings concerned and entail adverse consequences for them' at (para. 15, emphasis added). 
may be unsuited to properly representing the effective position of affected parties and, in current EU law, thus places them in an uncertain position regarding their procedural rights. In the field of state aid, for example, only recently have the Courts issued judgments which ensure procedural guarantees to the parties concerned, who, not being the addressees of state aid decisions, are called upon to participate, under Article 88(2) EC, in the procedure assessing the compatibility of an aid with Community rules. ${ }^{43}$

On the other hand, stances favourable to the procedural protection of interested persons are unlikely to come about through the Commission's practice: although this last welcomes sources of information and collaboration in the exercise of its regulatory functions, it is not willing to follow legal rules which could enshrine procedural rights to persons affected by its activity. ${ }^{44}$ Without denying that there are costs associated with participation and that ensuring a 'timely delivery of policy' is a worthy aim, this stance may, in certain cases, infringe human dignity as a value underlying the right to participate in procedures affecting one's rights and interests, for example, one's professional reputation. ${ }^{45}$

The current rules on the right to be heard are is at odds with a paradigm of administrative law which propounds rules and principles developed to ensure the correct exercise of the administrative function in respect of the rights and legitimate interests of citizens. It may be argued that the EU, predominantly focused on the goals of economic integration, is essentially output-oriented and that such a paradigm is either unsuited to EU administrative law or, at least, not inherent in the nature of the EU polity.

43 In Technische Glaswerke, cit., the Court reviewed the motivation of the Commission's decision in the light of its ability to allow 'the applicant, as a party concerned, to understand why its argument had been rejected' (para. 67; this was confirmed in appeal: Case C-404/04 P, Technische Glaswerke Ilmenau GmbH v. Commission [2007] ECR I-1, at para. 35). In Kuwait, the Court held that 'the Commission is obliged duly to place the interested parties in a position to put forward their comments in the course of a formal investigation procedure on State aid': Case T-354/99, Kuwait Petroleum (Nederland) BV v. Commission [2006] ECR II-1475, at para. 83 .

44 Communication from the Commission, 'Towards a reinforced culture of consultation', cit. (n. 17), pp. 10 and 15.

45 Case T-326/99, Nancy Fern Olivieri v. Commission [2003] ECR II-6053 where the Court, sanctioning the Commission's abovementioned stance, recognised the utility of the appointment's procedural intervention in a procedure for the approval of medicinal products, but denied her any guarantee which would enable her to assess how her contribution had been taken into account (paras 72 to 74 and 91). As to whether her professional reputation had been harmed in the whole procedure, the Court simply concluded that the applicable regulation did not allow the Commission to take these considerations into account (para. 97). 
This argument is, however, weak. It ignores the features of EU law which place the individual and the protection of his rights at the core of the EU legal system, namely the doctrine of direct effect, the conception of fundamental rights as part of the general principles of EU law and European citizenship. $^{46}$

Concomitantly, the status quo is problematic under the rule of law. It is submitted that, in a system respectful of the rule of law, the procedural protection of individuals and their legally protected interests affected by the exercise of the Union's administrative power needs to be a central concern. ${ }^{47}$ The fact that the Charter of Fundamental Rights recognises the rights of persons in their relationships with the European administration confirms that this aspect is not fully neglected by EU law. Nevertheless,

46 The 'motivations' or, possibly, claimed limitations of these features in securing the position of the individual in EC law do not override this statement. Direct effect has been instrumental in ensuring the effectiveness of EU law (Francis G. Jacobs, 'The Evolution of the European Legal Order' (2004) Common Market Law Review vol. 41, Issue 2, 303, at p. 308), as European citizenship may be considered as a tool for intensifying the process of integration and modest in view of the rights and duties of which it is composed (see Ulrich K. Preuss, 'The Relevance of the Concept of Citizenship for the Political and Constitutional Development of the EU', in Ulrich K. Preuss and Ferran Requejo Coll (eds), European Citizenship, Multiculturalism, and the State, Nomos (Baden-Baden, 1998) p. 11, at pp. 14-15). As to fundamental rights, it may be argued that the claims based on their violation have been weak in leading to the annulment of legislative acts, and, in addition, that the EU 'continues to be a weak actor as far as the promotion of human rights is concerned', apart from having double standards regarding its own members, on the one hand, and external actors, on the other (Paul Craig and Gráinne de Búrca, EU Law. Texts, Cases and Materials, 4th edition, Oxford University Press (Oxford, 2008), pp. 390-391 and 407-408; the quotation is from p. 408). In any case, these features do have the effect of giving the individual a central position in EU law. Regarding direct effect see Bruno de Witte, 'Direct Effect, Supremacy, and the Nature of the Legal Order', in P. Craig and G. de Búrca (eds.), The Evolution of EU Law, Oxford University Press (Oxford, 1999), pp. 177-213, at pp. 205-207). Despite the drawbacks pointed out, 'a strong commitment to human rights is one of the principle characteristics of the European Union' (Philip Alston and J.H.H. Weiler, "An "ever closer union" in Need of a Human Rights Policy: the European Union and Human Rights', in P. Alston et al. (eds.) The EU and Human Rights, Oxford University Press (Oxford, 1999), p. 6) and, admittedly, the status of European citizenship in itself entails the potential for reinforcing the position of the individual in the integration process (Preuss, cit., p. 25).

47 This concern is manifested in Case C-49/88, Al-Jubail Fertilizer Company (Samad) et Saudi Arabian Fertilizer Company (Safco) v. Council [1991] ECR I-3187, where the Court argued for a 'scrupulous' action of the Community institutions in view of the possibility that European rules might 'not provide all the procedural guarantees for the protection of the individual which may exist in certain national legal systems' (cit., para. 16). 
the corresponding provision, restating previous case law, suffers from the deficiencies pointed out above. ${ }^{48}$ Finally, in a regulatory system such as the Union's, where the decision-making power is spread across different levels connected under complex administrative procedures, one cannot rely for the purposes of procedural protection on the principle that participation is a matter to be left to national rules. Participation needs to occur at the stage of the procedure where the decisions are formed, in order to preserve its effet utile. ${ }^{49}$ In the light of what was argued above, this requires an extended procedural protection going beyond that afforded by the recognition of the right to be heard as a fundamental principle of EU law.

\section{PARTICIPATION RIGHTS AND THE PROCEDURAL PROTECTION OF HOLDERS OF LEGITIMATE INTERESTS}

\subsection{Underpinning Participation Rights: Concept of Participation}

Participation should be intended in a broader sense than the strict formulation of the right to be heard developed by the Community Courts. This is predominantly underpinned in a adversarial conception of the administrative procedure and arguably influenced by the requirement of individually and directly concerned persons, defined as a condition to access the judicial review of Community acts. ${ }^{50} \mathrm{~A}$ broader concept of participation is defined by reference to the persons whose intervention is considered legally relevant and to the functions of this intervention. On the one hand, the intervention of participants presupposes the entitlement of a substantive interest potentially affected by the outcome of the procedure. On the other, the legal relevance of the participants' intervention in the procedure is assessed in the light of two combined functions of participation: procedural protection of affected legal spheres (participation grounded on the person's dignity) and an accurate representation of the factual situation (participation as a means of gathering information and facilitating implementation and compliance structures in

\footnotetext{
48 Article 41 of the EU Charter of Fundamental Rights, OJ (2000) C364/1.

49 This has been recognised by the Courts (cf., e.g., Case T-346/94, Franceaviation v. Commission [1995] ECR II-2841, paras 30 and 34).

50 Article 230 (4) EC.
} 
the exercise of the decisional function). ${ }^{51}$ This combined criterion allows a stricter sense of procedural participation to be distinguished from the multiple meanings of participation and, particularly, from the somewhat disparate uses that especially the Commission has made of this concept in its governance initiatives. At the same time, the proposed criterion departs from the narrow judicial conception of participation rights: those affected are not necessarily directly and individually concerned and the acts covered by participation rights may be of a general nature as long as the conditions on which participation rights are grounded are fulfilled. These aspects will be dealt with below. First, however, two fundamental premises of participation should be clarified.

Firstly, the substantive relationship of interested parties to the procedure is the basis for a claim for participation rights; these are, in a sense, instrumental to the underlying substantive positions. In other words, the ultimate reason for the procedural intervention resides in a particular relation between the participant to the material situation which motivated the procedure. Access is restricted: the entity of reference of this concept of participation is not the citizen, nor the public, nor civil society indistinctly, but the person situated in a social group or setting which is affected by the decisional process. ${ }^{52}$ In short, participation rights should be granted to natural and legal persons who are the holders of individual and collective interests concerned by the final decision.

Secondly, this definition of participation assumes that a clear-cut distinction between a negative or subjective function of participation participation as defence grounded on the person's dignity - and a positive or objective function - participation as collaboration with the deciding body - cannot be upheld..$^{53}$ On the one hand, participation as collaboration entails the protection of the interests voiced in the procedure. On the other, when intervening to defend his interests, the participant collaborates in the decision-making process by providing information and

51 While these are the rationales underlying the Courts' case law on the right to be heard, the Courts' judgments have coined a restrictive stance regarding participation rights, for the reasons pointed out above. Moreover, as stated, they have essentially maintained a pragmatic approach, refraining from providing a coherent doctrinal basis grounded in these rationales.

52 Distinguishing two systems of representation (representative democracy and interest representation) by reference to the citizen and to 'l'homme situé' see Jean Boulois, 'Représentation et participation dans la vie politique et administrative', in La participation directe du citoyen à la vie politique et administrative. Travaux des XXI ${ }^{e s}$, Journée d'Études Juridiques Jean Dabin (12th) Francis Delpérée (second author) Bruylant (Bruxelles, 1986), p. 49, at pp. 50-51.

53 This clear-cut distinction underlies the Court's judgment in Nölle. 
alternative interpretations of the facts under assessment. Thus, the difference between the two functions is not qualitative, but merely quantitative, measured in the predominance of one function over the other, which in the end depends on the relevance of the personal factor in the underlying material situation. ${ }^{54}$ In addition, the enhancement of procedural rules which are likely to lead to correct outcomes, in so far as they ensure an accurate representation of the variables involved in decision-making, is a requirement of the rule of law, as is the respect for the person's dignity. Both are essential to the material justice of the final decision, which should be ensured beyond the formal correctness of the procedure. ${ }^{55}$ Therefore, a clear-cut distinction between the two rationales distorts and overly simplifies the conceptual and effective reality of participation. Both converge under the same legal principle - the rule of law - and the values warranted thereby.

It should, moreover, be noted that the eventual plural configuration of the content of the act resulting from a participative procedure, in the sense defended in the above paragraphs, does not in principle imply that administrative decisions should be consensual or based on a compromise between competing interests, and much less that the administration gives away its decision-making powers. While, admittedly, participation might lead to compromised solutions, it should strictly serve the functions pointed out above. In any event, 'responsibility [of the administration] for the decisions taken must be the limit to participation in the procedure'. ${ }^{56}$ Participants are not granted proper decision-making power within the decisional structure (at least, not in a legal sense). Their views may be taken into consideration, but the final act adopted does not need to mirror the interests voiced in the procedure.

54 As underlined by Cassese, the 'non-unity' of the theme of participation derives from the diversity of the position of the participant in relation to the subject matter underlying the procedure 'sometimes external or marginal to the procedure and to the function which the latter performs, sometimes, on the contrary, central and dominant' (Sabino Cassese, 'Il privato e il procedimento amministrativo', (1970) 79 Archivio Giuridico Filippo Serafini 25, at p. 31, author's translation).

55 David Duarte, Procedimentalização, participação e fundamentação: para uma concretização do princípio da imparcialidade administrativa como parâmetro decisório, Almedina (Coimbra, 1996), pp. 137-139, and, further, p. 166. Nevertheless, it is not ruled out that the quantitative difference may influence the content of participation (Craig, Administrative Law, cit. (n. 30), pp. 408-409 and 429-431).

56 Vasco Pereira da Silva, Em busca do acto administrativo perdido, Almedina (Coimbra, 1996), pp. 403-404. 


\subsection{Two Variables: Types of Power and Affected Interests}

It follows from the considerations presented above that the normative justification for participation rights depends on the convergence of two factors: there must be public interference in the legal sphere of legal or natural persons and a correlative change in these persons' advantageous or disadvantageous positions stemming from a public action. In other words, participation rights are justified where the regulatory activity of the Union institutions and bodies amounts to shaping administrative relationships between public and private entities, in the sense that they either define or decisively determine the content of the rights, interests, duties and charges recognised to or impinging upon the persons concerned.

The concept of administrative relationship, in the meaning conveyed here, encompasses the links established between different legal spheres, involving both public entities and natural and legal persons, creating or affecting rights, interests, charges and duties which emerge from the legal norms applicable to a certain material situation. They often involve more than two persons, in interrelated sets of favourable and unfavourable positions (complex administrative relationships), be they of a substantive or procedural nature. ${ }^{57}$

\subsubsection{Types of power}

The line dividing the type of power exerted which gives rise to the right to be heard is not so much that which distinguishes between discretionary and mandatory powers, as the Court of First Instance has held in recent controversial judgments. ${ }^{58}$ The decisive criterion is the end result of the administrative decision: whether it may or may not determine an advantageous or disadvantageous position for the persons concerned, for example, whether it may negatively impact on their fundamental rights or on previously recognised rights and legally protected interests, by restricting, suspending or extinguishing them, or whether it may constitute an onus in their regard or deny them a benefit sought. While the impact and meaning of participation may be different before the exercise of discretionary or of mandatory powers, the rationales underlying rights of participation are equally valid in both cases. Arguing that participation is relevant

57 On the concept of complex administrative relationships see Eberhard Schmidt-Assmann, La teoría general del derecho amministrativo como sistema, Marcial Pons (Madrid, 2003), pp. 25, 185 and 316; on procedural administrative relationship, idem, pp. 375-376.

58 Yusuf, cit., paras 326 to 329 and Kadi, cit., paras 254 to 259 (both pending appeal). 
only in the face of the exercise of a discretionary choice, in so far as it contributes towards structuring the process of deciding which solution is best compatible with the public interest, implies debasing the dignitarian rationale which underpins a 'stronger' meaning of participation. Further, even if one attributes a prevailing weight to the instrumental rationale of participation, participation is equally relevant where the decision-maker's choice is bound by objective parameters (i.e. the decision does not result from a discretionary appreciation, in a narrow sense) but the final decision entails nonetheless an assessment of technical or specialised knowledge. ${ }^{59}$ Lastly, and still under an eminently instrumental logic, even in cases of mandatory powers, the facts on the basis of which the administration decides may be controversial, the intervention of the persons affected in order better to define the issue under appraisal being useful.

Now, such powers may be manifested both through the enactment of an individual decision and through the adoption of a rule. First, the distinction between individual and general acts is far from clear, unless based on legal fictions. ${ }^{60} \mathrm{In}$ fact, the exertion of normative power conveys 'extremely

59 This recalls the distinction between discretionary powers proper and technical discretionarity. On this distinction see, among others, Bernardo Mattarella, 'Discrezionalità amministrativa', in Cassese (ed.), Dizionario di Diritto Pubblico, cit. (n. 21), vol. III, p. 1993, at p. 1006.

60 In EU law, take the example of anti-dumping regulations, of regulations which define the list of tradable products attesting to their compatibility with public health rules, or of the recent regulations adopting measures directed against the property of persons suspected of terrorist association. The first have been characterised as having a hybrid nature (in particular, the Opinion of AG Warner, quoted above, n. 35). The second may be considered general administrative acts: they are concrete, given that they refer to specific products and define their 'legal status', but general in effect, in so far as they define the conditions of use that must be abided by market operators dealing with them (on general administrative acts, referring to Italian administrative law, see Massimo Severo Giannini, Diritto amministrativo, 3rd edition, Giuffrè (Milan, 1993), vol. II, p. 288; they resemble the décisions d'espèce of French administrative law: see Réné Chapus, Droit administrative général, Monchrestien (Paris, 2008), pp. 516-522). Arguably, in the third case, administrative acts are adopted in the form of a regulation (the type of situation envisaged in Article 230(4) of the EC Treaty). The Court of First Instance provided a different interpretation. It considered that the fact that the persons named on the regulation 'appear to be' directly and individually concerned by it does not affect the general nature of the act, which determines an erga omnes prohibition on funding or making economic resources available to the persons named in the regulation (Yusuf, cit. (n. 28), para. 186), and overlooked the fact that the regulation in issue also determined that all funds and economic resources of the persons named in the regualtion's annex should be frozen (see paras 185 to 188 of the judgment). This interpretation was upheld by the Court of Justice (Kadi and Al Barakaat, cit., n. 28, paragraph 242). 
varied contents, of atypical symbolic expression (plans, graphs, chemical or mathematical formulae, etc.) and of varied subjective range', often blurring the distinction between the norm and the act that implements it. ${ }^{61}$ At the very least, one may maintain that there are different shades of general and abstract characteristics of regulations. Secondly, and consequently, acts of a general nature may impact on private legal spheres in a similar way to individual acts. Independently of the possibility of an administrative act being adopted under the form of a regulation, the regulation may intensively define the contours of the material situation in such a way as to decisively condition the content of the administrative relationships which will for part of its realm. ${ }^{62}$

\subsubsection{Affected interests}

As stated, the recognition of rights of participation needs to be related to the position of the individuals vis-à-vis the administrative decision. The concept of administrative relationship helps to delimit the range of persons who may be granted access to the procedure. On a first approach, these are all those who are somehow implicated in the administrative relationship which emerges from the public intervention. Two groups of interested persons should be distinguished: first, persons whose subjective rights and interests are directly affected by the outcome of the procedure, who can generally be termed holders of legitimate interests. Their access to the procedure is not strictly dependent on the 'ownership' of a right, or on a norm which is intended legally to protect the relevant interests of persons. ${ }^{63}$ More broadly, holders of legitimate interests are those whose legal sphere may be affected by the outcome of the procedure and whose legal position is protected and needs to be taken into consideration by the legal system, it being thus legally relevant. ${ }^{64}$ The second group consists of persons who voice interests protected by the legal system which, by force of the applicable legal norms, are pertinent to the regulation of the material situation under analysis, that is, holders of general interests. In this case, the interests voiced by participants are legally relevant in so far as their fulfilment is, in general, one of the goals of the legal system and, in

\footnotetext{
${ }_{61}$ Juan Alfonso Santamaria Pastor, Fundamentos de derecho administrativo, Ramon Areces (Madrid, 1988), vol. I, p. 712.

62 Craig, EU Administrative Law, cit. (n.17), pp. 319-321.

${ }_{63}$ This last statement recalls the German doctrine of the protection norm: Schmidt-Assmann, cit., pp. 86-88.

64 This notion derives from the concept of legitimate interest developed in Italian administrative law (Aldo Sandulli, Manuale di Diritto Amministrativo, XV edition, Jovene Editore (Naples, 1987), pp. 107-114).
} 
particular, of the pertinent rules and, thus, should be taken into account in the exercise of the administrative function. This embraces holders of diffuse interests, who may be individuals who have a certain relation of proximity with the subject matter in issue, or, more frequently, collective persons who are statutorily representative of these interests. ${ }^{65}$

Representatives of collective interests may be included in one or the other category, depending on their connection to the material situation: whether they intervene to represent the rights or to voice the interests of their associates who are directly implicated in the regulated matter, ${ }^{66}$ or whether they intervene because the interests that they represent are concerned by the matter being decided and, by force of the relevant legal rules, should be taken into consideration in the decision or rule adopted. In this role, in current EU governance arrangements, they are often associated to decisional procedures, but their ability to intervene depends essentially on the volition of the deciding body, not on a procedural rule of action imposed grounded on their relation to the material situation. ${ }^{67}$

\subsubsection{Procedural status}

The procedural status of participants or, more precisely, the procedural guarantees ancillary to their right to participate are different in the two

65 In essence, these correspond to the doctrinal categories of legitimate interest and factual interest which have been developed in the Italian administrative doctrine. On this see Sandulli, cit., pp. 104-114 and Giannini, cit., pp. 74-87. There has been a long dispute on the boundaries between them (among others, Leonardo Ferrara, 'Situazioni soggettive nei confronti della pubblica amministrazione' in Cassese (ed), Dizionario di Diritto Pubblico, cit., vol. VI, pp. 5376-5390; Mario Nigro, 'Ma che cos'è questo interesse legittimo? Interrogativi vecchi e nuovi punti di riflessione', [1987] Il foro italiano, 469-483) and, in particular, on where to place diffuse interests in this construction. It is not rarely that the Community Courts have resorted to categories of national law to develop European normative solutions. See, for example, Pierre Pescatore, 'Le recours dans la jurisprudence de la Cour de Justice des Communautés Européennes a des normes déduites de la comparaison des droits des États membres' (1980) 32 Revue Internationale de Droit Comparé 337. The author underlines that the Courts' comparative approach leads sometimes to the absorption by Community law of legal conceptions of a single Member State, given 'their evident utility or the judicial progress that they allow to accomplish' (p. 353). In this case, it is submitted that the categories mentioned are useful to enhance the procedural protection of private parties. In addition, as will be argued below, they are not completely unknown in European law.

${ }_{66}$ By analogy with the conditions set by the Courts' jurisprudence in order to consider an association directly and individually concerned, for the purposes of Article 230 (4). See, among others, Case C-78/03 P, Commission v. Aktionsgemeinschaft Recht und Eigentum eV [2005] ECR I-10737, at para. 70.

67 See Section 2, above. 
cases. Abstracting from the formal structure of the administrative decision, and underpinning the analysis of this matter with the concept of administrative relationship, holders of legitimate interests, irrespective of their quality as addressees of a decision or as so-called 'third parties', should in principle have a procedural status analogous to the one recognised to those entitled with a right to be heard, as this has been developed so far in the jurisprudence, save where a different solution results from specific legislation or is required by the circumstances of the case. In a way, this has been acknowledged by the Courts' jurisprudence, in cases where the right to be heard was, as such, granted to persons other than the addressee of a Commission decision. Thus, as mentioned, in Lisrestal the argument that the applicable regulation established a direct link between the Commission and the recipient of the assistance, beyond the formal structure of the procedure, framed the recognition of the right to be heard to the latter. ${ }^{6}$

Nevertheless, this principled claim is at odds with the current legal configuration of European competition law procedures under Regulation $1 / 2003$. These are fundamentally bilateral procedures. ${ }^{69}$ Complainants who, being holders of legitimate interests, are "closely associated with the proceedings ${ }^{70}$ are not afforded the same procedural guarantees as those entitled to a right to be heard. ${ }^{71}$ In addition, the approximation between the procedural rights of holders of legitimate interests - concretely, the

68 Lisrestal, cit., para. 47. See also Case T-102/00, Vlaams Fonds voor de Sociale Integratie van Personen met een Handicap v. Commission [2003] ECR II-2433, at para. 60.

69 Article 27 of Council Regulation 1/2003, of 16 December 2002, on the implementation of the rules on competition laid down in Articles 81 and 82 of the Treaty (OJ (2003) L 1/1). Cf. Articles 6, 11 and 13 of Council Regulation 773/2004, of 7 April 2004, relating to the conduct of proceedings by the Commission pursuant to Articles 81 and 82 of the EC Treaty (OJ (2004) L 123/18), as amended.

${ }_{70}$ Article 27(1) of Regulation 1/2003, cit. On their qualification as holders of legitimate interests, see below.

${ }_{71}$ The procedural rules defined are clear in this respect: the complainant has access only to the non-confidential part of the statement of objections and may, where the Commission finds it appropriate, participate in the oral hearing afforded to the parties against whom the procedure was initiated (Article 6 of Regulation 773/2004, cit., n. 69). The rule that the procedural rights of the complainants are not 'as far-reaching as the right to a fair hearing of the companies which are the object of the Commission's investigation' has been stated in Joined Cases 142 and 156/84, British-American Tobacco Company Ltd and R. J. Reynolds Industries Inc. v. Commission [1987] ECR 4487, at para. 20 (where it is underlined that 'the limits of [rights of complainants] are reached where they begin to interfere with those companies' right to a fair hearing') and in Case T-17/93, Matra Hachette SA v. Commission, [1994] ECR II-595, at paras 34 and 35. 
complainant - and the right to be heard of the addressee of the decision, where admitted, has been carefully grounded on the specific circumstances of the case. ${ }^{72}$ The assimilation of the participation rights of interested parties to the right to be heard of the addressee of an administrative decision was notably attempted in Sytraval, where the Court of First Instance sought to extend the procedural guarantees ancillary to the right to be heard to complainants in a state aid procedure. The judgment, however, distorted the procedural design determined by the combination of Article 88(2) and (3) and took the view that the state aid decision at issue had been addressed to the complainant. This was an incorrect interpretation, based on the will to react to react against an opaque procedure (that of Article 88(3)), and was quashed on appeal. ${ }^{73}$ To conclude this point, the 'justice' of the principled claim espoused above needs to be assessed in each case, in the light of the applicable rules and of the factual situation under valuation: either of these factors may hinder the extension of the procedural guarantees attached to the right to be heard to other parties to the proceedings.

As to holders of general interests, they may be afforded a weaker procedural position, given the predominance of the instrumental rationale underlying participation. In this sense, the deciding body may delimit the subject matter in relation to which it hears these interested parties, they may not be given access to the non-confidential part of the file and, while the statement of reasons must reveal the reasoning and the sources of information taken into account by the deciding body, the latter does not need to address the specific claims voiced by holders of general interests. The stronger procedural status of the holders of legitimate interests advocated above lies on the relevance of their personal position in relation to the subject matter being decided, since the final decision impinges upon their legal sphere, irrespective of its concrete addressee. The circles of interests which need to be considered by the decision-maker, the position of their holders and their corresponding degree of procedural protection result from the principles and norms which regulate the substance of the subject matter.

72 Case T-49/93, Société Internationale de Diffusion et d'Edition (SIDE) v. Commission [1995] ECR II-2501, at paras. 71 and 73. The Court considered that an exchange of views inter partes with the complainant would have been better suited to fully ensure the usefulness of the complainant's contribution to the procedure.

73 Case C-367/95 P, Commission v. Sytraval and Brink's France SARL [1998] ECR I-1719. 


\subsubsection{Legitimate interests and general interests in EU law}

Admittedly, these categories are not sufficiently developed in EU law (certainly not as general categories, independent of specific regulations and sector specificities), but they are also not unknown in this legal system. For example, according to Article 7(2) of Regulation 1/2003, other than Member States, only natural or legal persons demonstrating a legitimate interest are entitled to file a complaint in a competition law procedure. The Courts have accorded, for these purposes, a legitimate interest competitors of the undertakings targeted by the procedure, to persons whose economic activities may suffer injuries or losses as a result of the alleged infringement (including final customers who show that their 'economic interests have been harmed or are likely to be harmed as a result of [a] restriction of competition'), to associations of undertakings when the interests or their associates may be harmed by the claimed unlawful conduct. ${ }^{74}$ These correspond to the category of holders of legitimate interests defined above. It should be noted that the quality of complainant may also be recognised to interveners in an already initiated procedure: the Court of First Instance has held that a different solution would deprive holders of legitimate interests of exercising the procedural rights associated with the status of complainant. ${ }^{75}$ This reveals that the underlying concern is not to protect the procedural position of the complainant as such, that is, the person who triggers the administrative procedure, but of holders of legitimate interests in general, whose protection is granted by affording them the status of complainants.

On the other hand, other persons showing a 'sufficient interest' may be admitted to the procedure, either upon their own initiative (provided that the Commission considers their intervention necessary) or by invitation of the Commission. ${ }^{76}$ For example, 'consumer associations that apply to be heard should generally be regarded as having a sufficient interest, where the proceedings concern products or services used by the end-consumer or products or services that constitute a direct input into such products or

74 Ignace Maselis and Hans M. Gilliams, 'Rights of Complainants in Community Law', [1997] European Law Review 103, at p. 108. The possibility of final costumers being admitted as complainants was mooted in Joined Cases T-213/01 and 214/01, Österreichische Postsparkasse v. Commission [2006] ECR II-1601, at paras 114 to 119 .

75 Joined Cases T-213/01 and 214/01, Österreichische Postsparkasse v. Commission [2006] ECR II-1601, at para. 91 (cited n. 74 above). Joined Cases T-259-264 and 271/02, Raiffeisen Zentralbank Österreich and Others v. Commission, paras 95 to 103 .

76 Article 27(3) of Regulation 1/2003, cit. (n. 69), and Article 13 of Regulation 773/2004, cit. (n. 69). 
services. ${ }^{77}$ These interested parties, unlike holders of legitimate interests, are not directly implicated in the material situation that gave rise to the administrative procedure (for example, their economic interests are not affected by the infringement of competition rules), but they voice interests that are legally relevant in so far as they are protected by the legal system and are touched by the administrative procedure at issue. ${ }^{78}$ Therefore, even if the distinction between addressees and complainants is not necessarily defined along the lines espoused above, the proposed categorisation is grounded solidly in European competition law.

Likewise, the procedure to be followed for the registration of a Community trade mark entails, on the one hand, an opposition procedure which may be triggered by holders of legitimate interests whom the registration might harm (for example, proprietors of earlier trade marks that might be confused with the future trade mark). ${ }^{79}$ On the other, 'any natural or legal person and any group or body representing manufacturers, producers, suppliers of services, traders or consumers' - holders of general interests that might be concerned by the registration of the trade mark - may submit written observations explaining why this registration does not comply with the legally defined requirements. ${ }^{80}$ Their procedural status is different: in the first situation, opponents are parties to the proceedings before the Office for the Harmonisation of the Internal Market; in the second case, the observations are simply 'communicated to the applicant who may comment on them' ${ }^{81}$

In a similar vein, in anti-dumping procedures, a privileged procedural position is accorded to the undertakings concerned that are 'directly and individually' affected by an anti-dumping regulation which entails 'adverse consequences' for them, and, to a lesser degree, to those demonstrating a "sufficient interest as an "interested party"'.82 At the same time, the verification of the condition on which the Community intervention needs to

77 Regulation 773/2004, cit., recital 11.

78 Cf. Österreichische Postsparkasse, cit. (n. 74), at paras 114 to 119, in particular para. 115 .

79 Articles 42, 43 and 8 of Council Regulation 40/94, of 20 December 1993, on the Community trade mark (OJ (1994) L 11/1), as amended.

80 Articles 41 and 7 of Regulation 40/94, cit. (n. 79 above).

81 Cf. Article 41(2) and Article 43 of Regulation 40/94, cit. (n. 79), and Rule 19 of Commission Regulation 2868/95 of 13 December 1995 implementing Council Regulation 40/94 on the Community trade mark, OJ 1995 L 303/1.

82 Al-Jubail, cit. (n. 35), at para. 15; Nölle, cit. (n. 20), at para. 76; Articles 5(9) to (11), 6(5) to (7) and 20 of Regulation 384/96, of 22 December 1995, on protection against dumped imports from countries not members of the European Community, OJ (1996) L 56/1. 
be based - whether or not the imposition of anti-dumping measures is in the Community interest - is determined on the basis of 'an appreciation of all the various interests taken as a whole, including the interests of the domestic industry and users and consumers' ${ }^{83}$ For this purpose, interested parties, independently of a direct and individual concern, are given the opportunity to express their views on this issue (they may request a hearing upon justification) ${ }^{84}$ This right to participate in order to determine Community interest corresponds to the rights of participation of holders of general interests espoused above.

Access to the decisional procedures of holders of legitimate and of general interests may be extended by analogy to other fields of European law, where the Community decision is such that it originates or affects an administrative relationship established between the European administration and the persons concerned, irrespective of the form it takes. This may occur both when the final decision results from a centralised administrative procedure (i.e. those where the final act is formally and substantively taken by a Community institution, irrespective of the collaboration and intervention of national administrative bodies and entities) and when it stems from a decentralised procedure (i.e. a procedure that is started and concluded by a national administration; this last is the face of a network which involves the other national administrations, the Commission and, possibly, other Community administrative bodies whose contributions are decisive for the final outcome).

While one may argue that this wide scope of rights of participation, as far as holders of legitimate interests are concerned, results from the broadest judicial formulation of the right to be heard (according to which it is granted to natural or legal persons in relation to measures adversely affecting them), as stated, this is very much embedded in a adversarial understanding of the administrative procedure. This leads to a narrower scope and meaning of rights of participation than the one propounded in this chapter, and to their denial in circumstances where they should in principle be recognised, in the light of a conception of participation rights grounded in the concept of administrative relationship, of the reality of public interference in subjective legal spheres, and of the legal relevance of participation when seen essentially from an instrumental perspective.

83 Article 21(1) of Regulation 384/96, cit. (n. 82 above). Cf. Articles 7(1) and 9(4) of the same regulation.

${ }_{84}$ Article 21(2) and (3) of Regulation 384/96, cit. (n. 82). Case C-179/89, Bureau Européen des Unions de Consommateurs v. Commission [1991] ECR I-5709, at para. 28 (denying interested parties not directly and individually concerned access to the non-confidential file). 
In addition, even in its broader formulation, the right to be heard, in its current state of development, does not entail the possibility of recognising procedural guarantees of intervention to holders of general interests.

In the light of the construction proposed in this chapter, in the administrative procedure which leads to the authorisation to use smoke flavourings in or on food, food business operators, other than the person who initiated the procedure and who will possibly hold the authorisation, should be granted a right to participate, since, under the applicable regulation, they will need to comply with the conditions and restrictions attached to the authorisation in question. ${ }^{85}$ Their legitimate interests should, therefore, be taken into account by the deciding body. Similarly, where Community legislation determines that a public consultation should be held in a given decisional process, different procedural treatment should be given to holders of legitimate interests and to holders of general interests, along the lines espoused above, in so far as it is possible to distinguish them on the basis of the respective contributions and, in particular, of the arguments woven by those who claim a legitimate interest. This would thicken (or create) the procedural guarantees of interested parties, apparently unaccounted for under the vague wording of the norms providing for a public inquiry. ${ }^{86}$

To be sure, participation rights are not unlimited. They cede before the need to respect fundamental rights upheld by the legal system (for example, professional secrecy) and the need to ensure prompt and effective action when this is required by the protection of the public interest (for example, emergency situations). ${ }^{87}$ Both limits need to be justified and fettered by legal principles. For example, regarding the failure to observe the rights of the defence regarding measures adopted to control foot-andmouth disease, the Court has held that eventual restrictions need to 'correspond to objectives of general interest pursued by the measure in question' and should not 'constitute, with regard to the objectives pursued, a disproportionate and intolerable interference which infringes upon the very substance of the rights guaranteed' ${ }^{88}$ This limit is certainly stricter

\footnotetext{
85 Article 9(4) of Regulation 2065/2003, cit. (n. 40).
}

86 E.g. '[t]he public may make comments to the Commission within 30 days from such publication' (Article 6(7) of Regulation 1829/2003, of the European Parliament and of the Council of 22 September 2003, on genetically modified food and feed, OJ (2003) L 268/1.

87 See, respectively Article 16 of Regulation 773/2004, cit. (n. 69), and Case C-28/05, G.J. Dokter and others v. Minister van Landbouw, Natuur en Voedselkwaliteit, [2006] ECR I-5431, paras 75-78.

${ }_{88}$ Dokter, cit. (n. 87 above), at para. 75 . In particular, interested parties should be given a right to contest the adopted measure in subsequent proceedings (para. 76). 
in the presence of fundamental rights (for example, measures affecting the liberty, the property or the good name of a person) than in the presence of legitimate interests, and is more meaningful in these cases than in relation to the participation rights of holders of general interests. In other words, the limits to the relative nature of participation rights are much stronger when the protection of fundamental rights is at stake.

As for the consequences of enlarging access to decisional procedures on the grounds defended in this chapter, although ideally holders of legitimate interests should be afforded locus standi to challenge decisions which, affecting them, have infringed rules of procedure and, in particular, their own procedural guarantees, it is well known that the requirement of direct and individual concern of Article 230(4), as it has been interpreted by the Courts, raises obstacles to this enlargement of locus standi. It could be argued that, despite the interconnections between access to procedure and access to judicial review, there is no need for the former to be conditioned by the latter. One could maintain that broader access to the decisional procedure, grounded on the enhancement of the procedural conditions for material justice, need not be matched by similar rules of standing directed at ensuring the observance of the law in the interpretation and application of the Treaty. ${ }^{89}$ Admittedly, however, loosening the entitlement of participation rights would create a tension on the European legal system, straining the limits of standing. In this light, the Courts' stance can undoubtedly be said to have a formal justification. Nevertheless, in the face of the considerations put forward in this chapter, one may question whether that tension is not already a reality, adding to the widely discussed reasons for enlarging the access of non-privileged applicants. ${ }^{90}$

\section{CONCLUSION}

Returning to the meanings of participation presented in this chapter, consideration for the dignity of the persons affected by Community action is perhaps the element which has had least attention in the midst of the European governance developments and, at the same time, the element which is capable of grounding stricter forms of participation rights in a

89 Article 220 EC.

90 Among others, Anthony Arnull, 'Private Applicants and the Action for Annulment under Article 173 of the EC Treaty', (1995) Common Market Law Review, vol. 32, Issue 1 7; Albertina Albors-Llorens, 'The Standing of Private Parties to Challenge Community Measures: has the European Court Missed the Boat?', [2003] Cambridge Law Journal 72. 
large segment of European decision-making. The increased resort to participation in European governance arrangements, grounded essentially on the instrumental advantages of participation, contrasts with the lack of concern for the position of the person affected in his rights and interests by the regulatory measures adopted by European institutions. On the other hand, the Courts' position in relation to participation rights is excessively restrictive to account for the procedural protection of the interests of the person touched by decisional processes.

A concept of participation underpinned, concomitantly, by the dignitarian (referring to the fundamental dignity of the person) and by the instrumental functions of the procedural intervention of persons concerned, and framed by the concept of the administrative relationship, has the advantages of extending the procedural protection of the persons whose legal sphere is affected by Community action and, consequently, of bridging the distance between the configuration of participation in the political realm, on the one hand, and legal realm, on the other. Consequently, the EU administrative legal system will better suit the requirements of the rule of law, in so far as the conditions for materially achieving just decisions are enhanced. In addition, this would enhance a paradigm of administrative law that is respectful of the rights and legitimate interests of the citizens and more consonant with constitutional features of the EU such as direct effect, respect for fundamental rights and the status of European citizenship.

While the Courts have grounded the right to be heard on the two rationales of participation mentioned, their approach has been inconsistent: on the one hand, they have been biased by an adversarial conception of procedures and process rights, and, on the other, limited by the limits to standing while, at the same time (on occasion, admittedly), they have been aware of both the moral imperative and instrumental usefulness of participation. 